\title{
Geodetic implications on block formation and geodynamic domains in the South Shetland Islands, Antarctic Peninsula
}

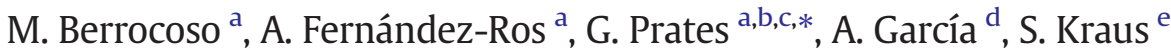 \\ a Laboratorio de Astronomía, Geodesia y Cartografía, Universidad de Cádiz, Cádiz, Spain \\ b Centro de Estudos Geográficos, IGOT, Universidade de Lisboa, Lisboa, Portugal \\ c Instituto Superior de Engenharia, Universidade do Algarve, Faro, Portugal \\ d Instituto de Geociencias, CSIC-UCM, Consejo Superior de Investigaciones Científicas, Madrid, Spain \\ e Northern Territory Geological Survey (NTGS), Darwin, Australia
}

\section{A R T I C L E I N F O}

\section{Article history:}

Received 10 February 2015

Received in revised form 20 October 2015

Accepted 26 October 2015

Available online 12 November 2015

\section{Keywords:}

Geodesy

Tectonic deformation

Geodynamic regions

South Shetland Islands

Antarctic Peninsula

\begin{abstract}
A B S T R A C T
The South Shetland Islands archipelago is dynamically complex due to its tectonic surroundings. Most islands are part of a formerly active volcanic arc, although Deception, Penguin and Bridgeman Islands, as well as several submarine volcanoes, are characterized by active back-arc volcanism. Geodetic benchmarks were deployed and the movement of the lithosphere to which they were fixed measured to provide geodynamic insight for the South Shetland Islands, Bransfield Basin and Antarctic Peninsula area based on surface deformation. These benchmarks' data add spatial and temporal coverage to previous results. The results reveal two different geodynamic patterns, each confined to a distinct part of the South Shetland Islands archipelago. The inferred absolute horizontal velocity vectors for the benchmarks in the northeastern part of the archipelago are consistent with the opening of the Bransfield Basin, while benchmark vectors in the southwestern part of the archipelago are similar to those of the benchmarks on the Antarctic Peninsula. In between, Snow, Deception and Livingston Islands represent a transition zone. In this area, the horizontal velocity vectors relative to the Antarctic plate shift northeastwards from $\mathrm{N}$ to NW. Furthermore, the South Shetland Islands benchmarks, except for that at Gibbs (Elephant) Islands, indicate subsidence, which might be a consequence of the slab roll-back at the South Shetland Trench. In contrast, the uplift revealed by the Antarctic Peninsula benchmarks suggests glacial isostatic adjustment after the Larson B ice-shelf breakup.
\end{abstract}

(c) 2015 Elsevier B.V. All rights reserved.

\section{Geological background and tectonic setting}

The region defined by the South Shetland Islands archipelago, the Bransfield Basin and the Antarctic Peninsula is characterized by highly complex and unique geotectonic surroundings. Today, two major tectonic plates are converging in the area, the South American and the Antarctic Plates. Furthermore, several minor tectonic plates are interacting, namely the Scotia, Phoenix and South Shetland Plates (Galindo-Zaldivar et al., 2004; Maestro et al., 2007) (Fig. 1).

The Antarctic Peninsula magmatic arc developed as part of the Andean-Antarctic continental margin from late Triassic to recent times. Subduction of the long-lived Phoenix Microplate ocean floor beneath the South Shetland Islands archipelago and its development as a separate magmatic arc began during the Cretaceous, though arc volcanism may have ceased at about 20 Ma (Fretzdorff et al., 2004; Smellie et al., 1984). Thus, the part of the volcanic arc located in the South Shetland Islands belongs to a much younger phase in geodynamic history.

\footnotetext{
* Corresponding author at: Instituto Superior de Engenharia, Universidade do Algarve, Faro, Portugal.

E-mail address: gprates@ualg.pt (G. Prates).
}

The spreading center in the western Drake Passage became virtually inactive about 3.3 Ma ago (Barker, 1976, 1982; Barker et al., 1991; Jin et al., 2009; Larter and Barker, 1991; Livermore et al., 2000; Robertson-Maurice et al., 2003) and the South Shetland Trench was partly filled with sediments. To the north, the South Shetland Trench ends at the left-lateral Shackleton Fracture Zone near Elephant Island, and to the south at the Hero Fracture Zone (Galindo-Zaldivar et al., 2004; Maestro et al., 2007).

Today, this last part of the formerly much larger subduction zone is the only area around the entire Antarctic continent where subduction still takes place, though at very low velocities (Barker, 1982). Assuming that subduction is still continuing, the rate should resemble that of the opening of Bransfield Basin, which is estimated at approximately $10 \mathrm{~mm} /$ year (Dietrich et al., 2000). Indeed, a convergence rate of close to $10 \mathrm{~mm} /$ year has been determined at the South Shetland Trench (Dietrich et al., 2001, 2004; González-Ferrán, 1991; Jiang et al., 2009; Taylor et al., 2008) and attributed to the NNW-SSE Bransfield Basin extension and to the Phoenix Microplate shortening or subduction. Based on the displacement of the South Shetland Islands to the NW, the amount of stretching and the width of new oceanic crust formed during rifting and spreading in the Bransfield basin area, Henriet et al. (1992) 


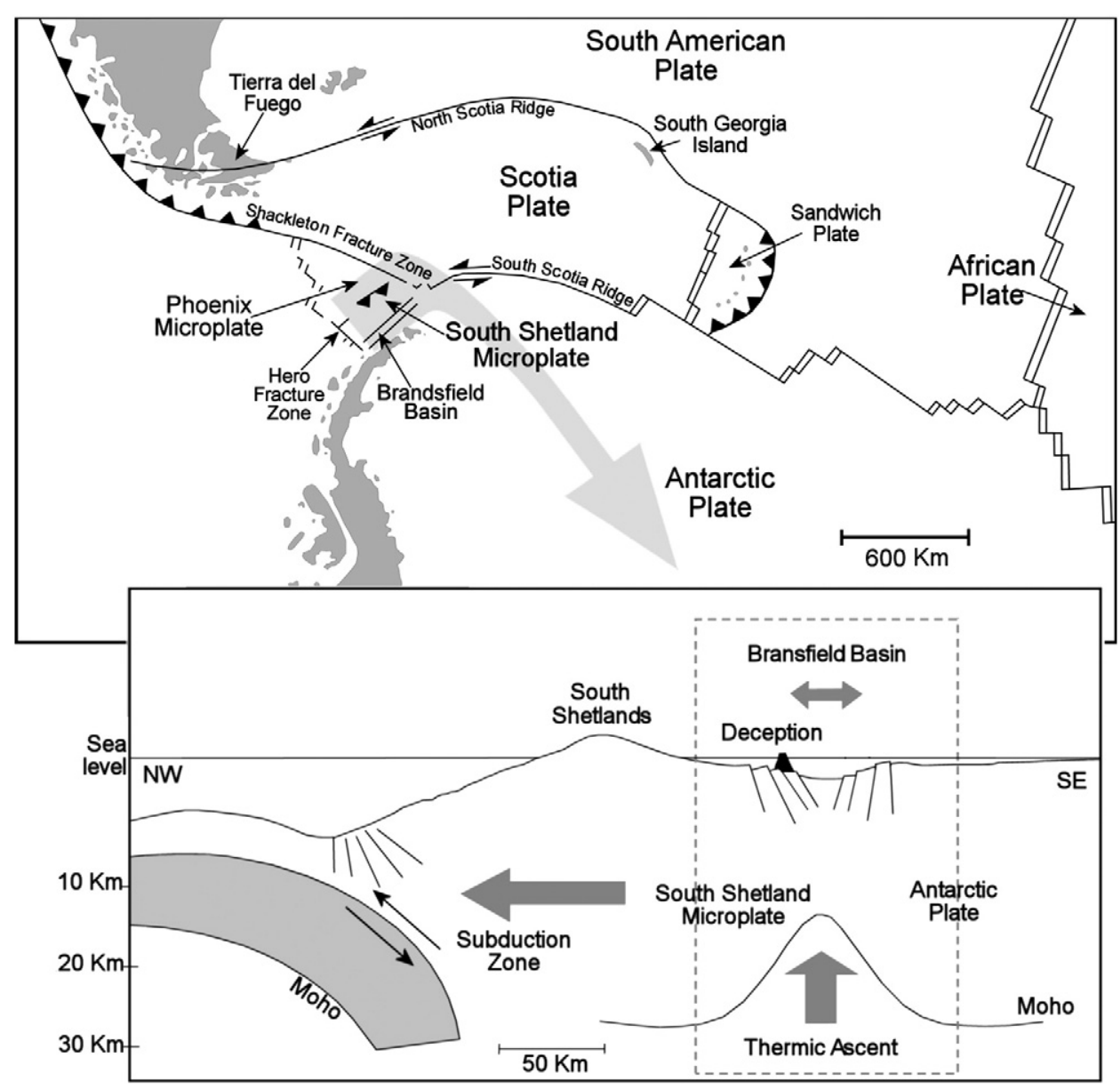

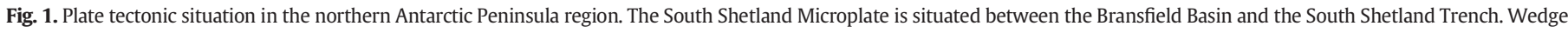

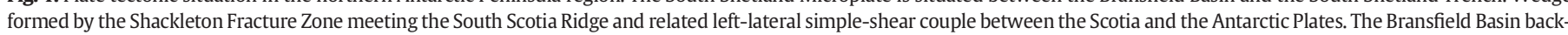
arc opening separates the South Shetland volcanic arc from the Antarctic Peninsula.

estimate for the South Shetland Trench convergence rates of 2.5 to 7.5 $\mathrm{mm}$ /year during the last $2 \mathrm{Ma}$. Recent seismic data also suggest convergence along the South Shetland subduction zone, with earthquake locations indicating an association of seismicity with slow subduction of young lithosphere, rifting, active volcanism and transcurrent plate boundaries (Robertson et al., 2002).

Due to the regional northeastwards movement of the Antarctic Plate, the South Shetland Trench has an additional left-lateral component that extends to the also left-lateral South Scotia Ridge, the Antarctic-Scotia boundary (Maestro et al., 2007). This setting might compete with the slab roll-back at the South Shetland Trench as the main mechanism behind the Bransfield Basin extensional regime (Galindo-Zaldivar et al., 2004; Maestro et al., 2007; Solari et al., 2008). These mechanisms cause the nearly orthogonal fault system, trending NNW-SSE and NNE-SSW, which has been recognized in the Bransfield Basin region (Maestro et al., 2007). Nevertheless, in addition to plate subduction and slab roll-back, the propagation of the South Scotia Ridge southwestwards beyond the Shackleton Fracture Zone is also thought to contribute to the transtensional regime in the Bransfield Basin region (Fretzdorff et al., 2004; González-Casado et al., 2000). Thus, the Bransfield Basin is possibly not a back-arc basin sensu strictu, as its opening might be related to left-lateral simple-shear couple between the Scotia and the Antarctic Plates (González-Casado et al., 2000).

The tectonic setting of the region is reflected in the modern volcanism along the western side of the northern Antarctic Peninsula. Starting shortly after about $4 \mathrm{Ma}$ ago, the slow subduction rate led to crustal extension and rifting processes which opened the Bransfield Basin between the Antarctic Peninsula and the South Shetland Islands.
Similar extensional processes on the eastern side of the Antarctic Peninsula are responsible for the volcanism along the Larsen Rift (González-Ferrán, 1983, 1995; Kraus et al., 2013). The back-arc volcanism within the Bransfield Basin is characterized by emergent volcanoes like Deception, Penguin and Bridgeman Islands, plus several submarine volcanoes at different evolutionary stages that are aligned along the NNE-SSW main direction of the basin (Canals et al., 1997).

Deception Island, the largest and most active volcano in the area, is situated $\sim 40 \mathrm{~km}$ south of Livingston Island close to the nascent spreading axis of the immature Bransfield Basin back-arc. The upper crustal structure of the area comprises continental crust north of Deception Island and more basic crust to the south (Muñoz-Martín et al., 2005). The tectonic setting of the volcano has been described as extensional, with maximum horizontal shortening in NE-SW and NW-SE directions (Pérez-López et al., 2007) and local compressional stress states (Maestro et al., 2007). Geometrical relationships between the location and orientation of joints and faults indicate two evolutionary phases, implying a counter-clockwise rotation of Deception Island which might be related to regional left-lateral strike-slip movements. In recent years the geodetically inferred NNE-SSW compression rate was higher than the NNW-SSE extension rate at Deception Island (Berrocoso et al., 2012; Prates, 2012; Prates et al., 2013). Recent paleostress regimes were determined for Deception Island (Maestro et al., 2007) and Byers Peninsula on Livingston Island (Alfaro et al., 2010), showing similar patterns following a NNW-SSE to NNE-SSW extension related to the Bransfield Basin opening and left-lateral transtension at the AntarcticPhoenix boundary, as well as NE-SW and NW-SE compressional states related to the Antarctic-Scotia convergence and the Phoenix Microplate 
subduction, respectively. On Byers Peninsula, the NW-SE maximum has been recognized in the northwest, while in the southern part of the peninsula NE to ENE directions become prevalent (Alfaro et al., 2010). This stress field favors block faulting and their subsequent counterclockwise rotation, in both the South Shetland Islands archipelago and the Bransfield Basin (Maestro et al., 2007). Studies on King George Island (Kraus et al., 2010; Smellie et al., 1984; Tokarski, 1991; Uhlein et al., 1993) and Elephant Island (Galindo-Zaldivar et al., 2006; López-Martínez et al., 2006) showed that the northern South Shetland Islands archipelago is dominated by NE-SW and NW-SE compressions.

\section{Geodetic network and methodology}

Since 1992, the tectonic behavior of the Antarctic Peninsula in relation to the South Shetland Islands archipelago and South America has been the motivation for several projects supported by SCAR (Scientific Committee on Antarctic Research). These projects included episodic campaigns using the increasing number of Global Navigation Satellite Systems (GNSS), mostly Global Positioning System (GPS), on benchmarks distributed along this region. The analysis of SCAR campaigns carried out between 1995 and 1998 yields a geodynamic model based on both horizontal and vertical surface deformation in the South Shetland Islands and the Antarctic Peninsula region, and an interpretation in the context of the Antarctic Plate (Dietrich et al., 2001, 2004). This model confirms the Bransfield Basin to open at a rate of $7 \mathrm{~mm} /$ year in NNW direction, and an Antarctic Peninsula uplift at variable rates reaching up to $2 \mathrm{~mm} / \mathrm{year}$, which is inferred to be related to postglacial rebound processes. Furthermore, a rotation Euler pole for the Antarctic Plate near latitude $63.0^{\circ} \mathrm{N}$ and longitude $125.3^{\circ} \mathrm{W}$ and an angular rotation velocity of about $0.229^{\circ} / \mathrm{Ma}$ in the ITRF2000 were computed (Dietrich et al., 2004). Considering the SCAR campaigns between 1997 and 2004, new values were obtained for the Euler pole near latitude $58.69^{\circ} \mathrm{N}$ and longitude $128.29^{\circ} \mathrm{W}$ and an angular rotation velocity of about $0.224^{\circ} / \mathrm{Ma}$ also in the ITRF2000 reference frame (Jiang et al., 2009). Adding new data to previous results of Thomas et al. (2003),
Dietrich et al. (2004) and Smalley et al. (2007), two independent blocks were identified based on their respective benchmarks' velocities, separating central King George, Greenwich, and Livingston Islands from southwestern Smith and Low Islands, without constraining precisely how and where this separation occurred (Taylor et al., 2008). The post-glacial rebound at the Antarctic Peninsula was also observed, however, in King George Island subsidence was inferred at two benchmarks (Bevis et al., 2009; Jiang et al., 2009).

To contribute to the identification of a geodynamic model for the South Shetland Islands, Bransfield Basin and Antarctic Peninsula region based on surface deformation, the Spanish Antarctic geodetic network (RGAE network) was deployed from 1987 onwards. It comprises several benchmarks with precise coordinates in the ITRF reference frame sequence (Berrocoso et al., 2008). Since 2007, the RGAE geodetic network consists of 12 benchmarks, BEJC and BYER on Livingston Island, BEGC on Deception Island, ILOW on Low Island, SNOW on Snow Island, MELU on Half-Moon Island, YANK on Greenwich Island, CPER on Robert Island, ARMO on Nelson Island, PENG on Penguin Island, and CACI and BROW in the Antarctic Peninsula (Fig. 2a). In this study, only BROW, ILOW, SNOW, BEGC, BYER, BEJC and PENG will be assessed. Moreover, OHI2 at O'Higgins Station and PALM at Palmer Station were added, both in the Antarctic Peninsula and included in the IGS (International GNSS Service) global network. While the BEJC and BEGC benchmarks were observed continuously during all austral summer campaigns since 2001-2002, the remaining RGAE benchmarks were only episodically observed. In order to ensure a correct and precisely determined position of the GNSS-GPS antenna center relative to the benchmark at each campaign, a forced centering system has been designed based on a $5 \mathrm{~cm}$ stainless steel screw for the benchmark materialization and a high-precision measured prolongation of nearly $13 \mathrm{~cm}$ to attach the antenna (Fig. 2b). The employment of the same antenna and prolongation pairs in each benchmark ensures the same antenna center location and antenna orientation between campaigns.

All data have been processed using the scientific software Bernese v5.0 (Dach et al., 2007). The benchmarks' coordinates from 2002 until

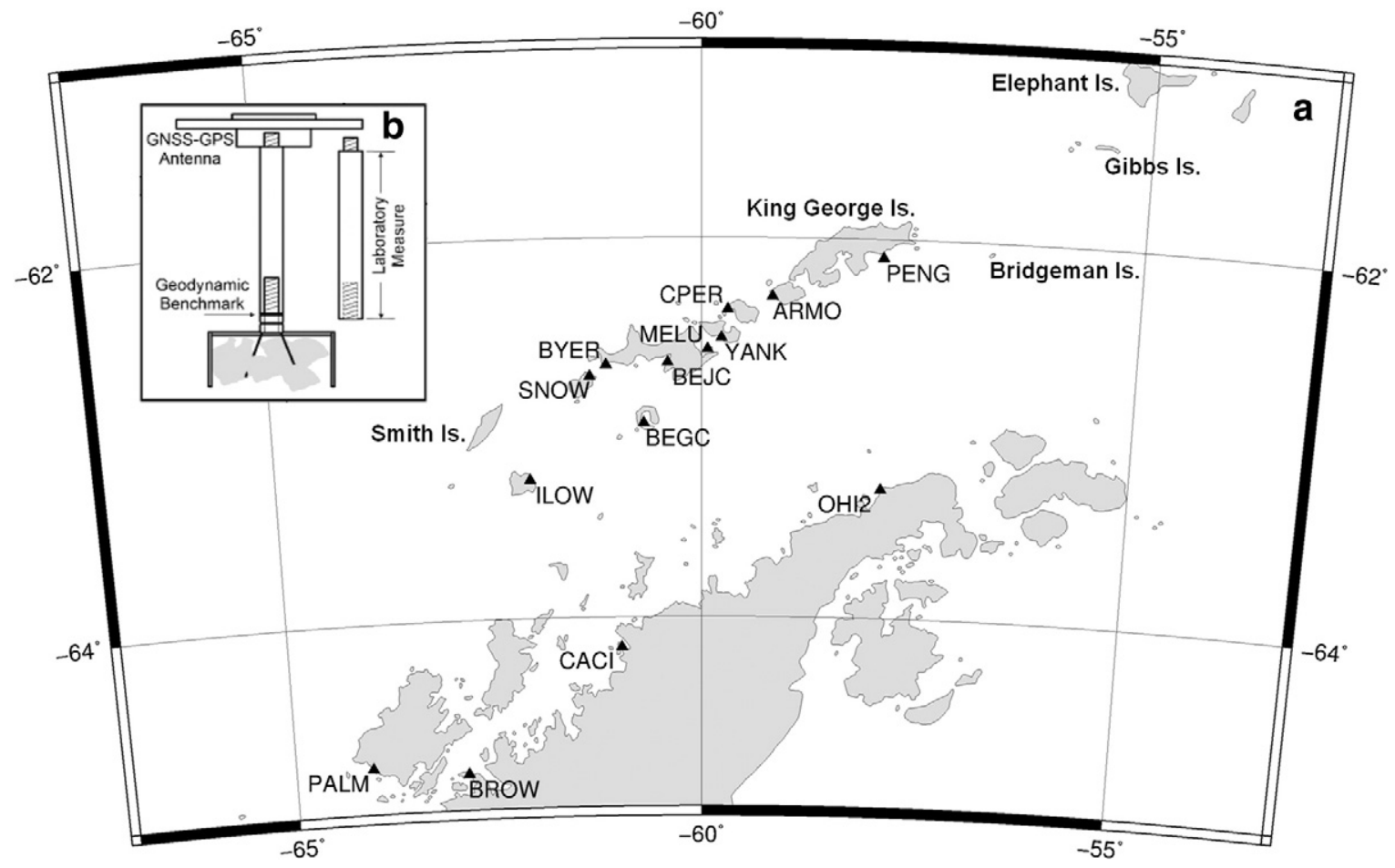

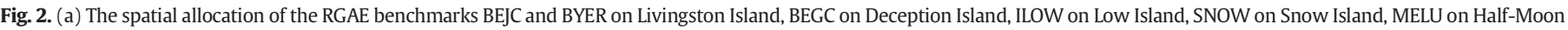

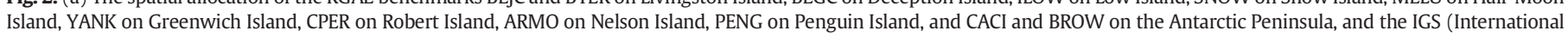
GNSS Service) benchmarks OHI2 and PALM. (b) The developed antenna position forced centering system. 
2014 were estimated considering 24 h sessions, $10^{\circ}$ elevation masks and a $30 \mathrm{~s}$ sampling rate. Since the software is based on relative positioning, the daily set of baselines was combined in a network adjustment which involves every benchmark each day. During the parameter estimation process, carrier phase double-difference data was used in an ionospheric delay free mode. Tropospheric errors were dealt with by using a combination of the a priori Saastamoinen model (Saastamoinen, 1973) and Neill mapping functions (Niell, 1996). Tropospheric parameters were estimated hourly, and ambiguities were resolved for each baseline independently, using the ionosphere-free observable with an a priori ionospheric model for determining the widelane ambiguity (Mervart, 1995). The ocean tide loading displacement corrections from Onsala Observatory were also introduced. The normal equations were computed for each daily solution. Finally, the campaign solution was achieved by combining the daily normal equations at the mean epoch of each campaign, using the IGS final orbits and constraining the movement of one reference benchmark, PALM at Palmer Station, for the realization of the ITRF2008 reference frame (Altamini et al., 2011). Also, one control benchmark was analyzed, $\mathrm{OHI} 2$ at O'Higgins Station, to validate the inferred velocities against those expected in the ITRF2008 reference frame.

\section{Processing results and analysis}

Time series of the benchmarks' position solutions in the ITRF2008 reference frame at each campaign were produced and from them the horizontal and vertical absolute velocities were computed. The inferred velocities in easting, northing and height, and corresponding precision, are shown in Table 1. Each benchmark time series include all geodynamic processes that affect them. Fig. 3 shows the time series of BEJC on Livingston Island and of BEGC on Deception Island. While the former exhibits nearly linear trends, particularly concerning its horizontal position components, the latter shows less linear trends in both horizontal and vertical position components. This is interpreted to be mostly due to Deception Island's volcanic activity (Berrocoso et al., 2006; Berrocoso et al., 2012; Carmona et al., 2012; García et al., 2002; Ibañez et al., 2000; Ibañez et al., 2003; Prates et al., 2013).

The absolute horizontal velocity vectors are in agreement with those determined by Dietrich et al. (2004), both in the Antarctic Peninsula and the northeastern South Shetland Islands (Fig. 4), although they are relative to different reference frame realizations. All Antarctic Peninsula benchmarks follow the northeastward movement imposed by the Antarctic Plate rotation in this region, and both PENG, BEJC and BYER movements are similar with those determined for ELE1, GRW1 and PRA1 by other authors (Dietrich et al., 2004; Jiang et al., 2009). However, the benchmarks situated in the southwestern part of the archipelago, ILOW, SNOW and BEGC, have horizontal velocity vectors more similar to those inferred for the Antarctic Peninsula (Fig. 4).

The absolute vertical velocity vectors are consistent in the Antarctic Peninsula (Fig. 5), all of them giving evidence for uplift. Furthermore, CACI and BROW inferred uplift rates have magnitudes near those inferred by a viscoelastic response model to the Larson B ice-shelf breakup
(Nield et al., 2014). However, our benchmarks from the South Shetland Islands show subsidence instead of uplift, contrasting with previously published data (Dietrich et al., 2004). Subsidence has also been reported from two benchmarks on King George Island (Bevis et al., 2009; Jiang et al., 2009) (Fig. 5).

Then the Antarctic Plate horizontal velocity vectors were subtracted from the absolute horizontal velocity vectors determined for each benchmark (Fig. 4), computed for the Antarctic Peninsula and South Shetland Islands region by an Euler rotation with Euler pole located at latitude $65.42^{\circ} \mathrm{N}$ and longitude $118.11^{\circ} \mathrm{W}$, and angular rotation velocity of $0.250^{\circ} / \mathrm{Ma}$ in the ITRF2005 (Argus et al., 2011a). By removing the superimposed tectonic movement of the Antarctic Plate, these smaller horizontal velocity vectors are relative to the Antarctic Plate and therefore its regional origin can be assessed (Fig. 6).

In the South Shetland Islands, the horizontal velocities relative to the Antarctic Plate present similar magnitudes. However, based on their directions, a rotation is inferred between SNOW on Snow Island and BYER on Livingston Island. ILOW and SNOW benchmarks shows relative velocities aligning nearly $\mathrm{N}$, while BYER, BEGC and BEJC exhibit relative velocities shifting to NW (Fig. 6).

\section{Proposed geodynamic model}

Based on the new data presented here, two geodynamic patterns can be differentiated in the South Shetland Island archipelago. One comprises Low, Smith and Snow Islands (the southwestern region), and another comprising the islands from Deception and Livingston to Elephant (the northeastern region) (Fig. 6).

The movement in the northeastern region is a consequence of the Bransfield Basin extension. The relative velocity directions suggest a transtensional propagation of the South Scotia Ridge southwestward through the Bransfield Basin (Fig. 7). This is indicated by the WNW velocity direction of the Gibbs (Elephant) benchmark, shifting to a NW direction between Penguin and Livingston Islands in the area of the most active and extended central section of the Bransfield Basin. The subsidence indicated by this region's benchmarks may be related to processes acting along the South Shetland Trench, e.g. a potential Phoenix Microplate roll-back underneath the South Shetland Microplate, which is one of the suggested mechanisms resulting in the Bransfield Basin extensional regime (Fretzdorff et al., 2004; González-Casado et al., 2000; González-Ferrán, 1991; Maestro et al., 2007; Prieto et al., 1998).

The southwestern region benchmarks on Low and Snow Islands reflect a different extensional orientation, less perpendicular to the Bransfield Basin NNE-SSW direction as those of the northwestern region, and with a southwestwards smaller subsidence regime. Although no benchmark was directly observed on Smith Island, Taylor et al. (2008) have inferred a similar horizontal velocity that of Low Island. Therefore, this region is lesser affected southwestwards by the processes acting along the South Shetland trench and the Bransfield Basin extension (Barker et al., 2003; Canals et al., 1997; Galindo-Zaldívar et al., 2004; González-Ferrán, 1991; Prieto et al., 1998).

Table 1

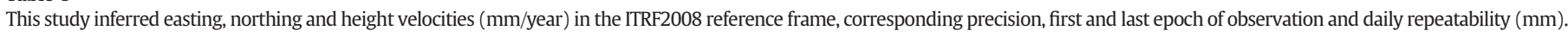

\begin{tabular}{|c|c|c|c|c|c|c|c|c|c|c|c|c|c|}
\hline Acron. & Lat. & Lon. & $\begin{array}{l}\text { Easting } \\
\mathrm{mm} / \text { year }\end{array}$ & $\begin{array}{l}\text { Northing } \\
\text { mm/year }\end{array}$ & $\begin{array}{l}\text { Height } \\
\text { mm/year }\end{array}$ & $\sigma_{\mathrm{e}}$ & $\sigma_{\mathrm{n}}$ & $\sigma_{\mathrm{h}}$ & First & Last & $\begin{array}{l}\text { Easting } \\
\text { repeat }\end{array}$ & $\begin{array}{l}\text { Northing } \\
\text { repeat }\end{array}$ & $\begin{array}{l}\text { Height } \\
\text { repeat }\end{array}$ \\
\hline BYER & -62.6664 & -61.0992 & 11.5 & 17.0 & -8.1 & 0.3 & 2.3 & 1.7 & 2007.0 & 2012.1 & 1.2 & 1.1 & 5.0 \\
\hline SNOW & -62.7284 & -61.2910 & 17.3 & 19.0 & -6.9 & 0.8 & 1.4 & 2.2 & 2006.9 & 2008.0 & 2.3 & 1.1 & 2.0 \\
\hline ILOW & -63.2711 & -62.0088 & 17.0 & 19.4 & -3.0 & 0.6 & 1.0 & 1.6 & 2006.9 & 2008.0 & 1.5 & 1.2 & 2.8 \\
\hline BEJC & -62.6630 & -60.3889 & 11.7 & 16.7 & -2.0 & 1.0 & 0.5 & 0.9 & 2002.0 & 2014.1 & 1.8 & 1.7 & 4.6 \\
\hline OHI2 & -63.3210 & -57.9000 & 15.1 & 10.6 & 2.0 & 0.2 & 0.1 & 0.5 & 2002.1 & 2014.1 & 1.7 & 2.1 & 3.4 \\
\hline CACI & -64.1558 & -60.9570 & 16.2 & 14.7 & 15.1 & 1.0 & 1.5 & 8.0 & 2004.0 & 2008.1 & 0.6 & 0.8 & 1.9 \\
\hline BEGC & -62.9788 & -60.6743 & 13.5 & 14.6 & -6.0 & 0.8 & 1.0 & 0.9 & 2002.0 & 2014.1 & 1.5 & 1.5 & 3.2 \\
\hline PENG & -62.0993 & -57.9368 & 6.3 & 19.8 & -7.6 & 4.1 & 9.1 & 4.1 & 2007.0 & 2012.1 & 1.1 & 1.6 & 2.2 \\
\hline BROW & -64.8060 & -62.8701 & 17.3 & 10.5 & 17.7 & 0.4 & 0.7 & 1.1 & 2007.1 & 2008.1 & 3.1 & 2.0 & 3.8 \\
\hline
\end{tabular}




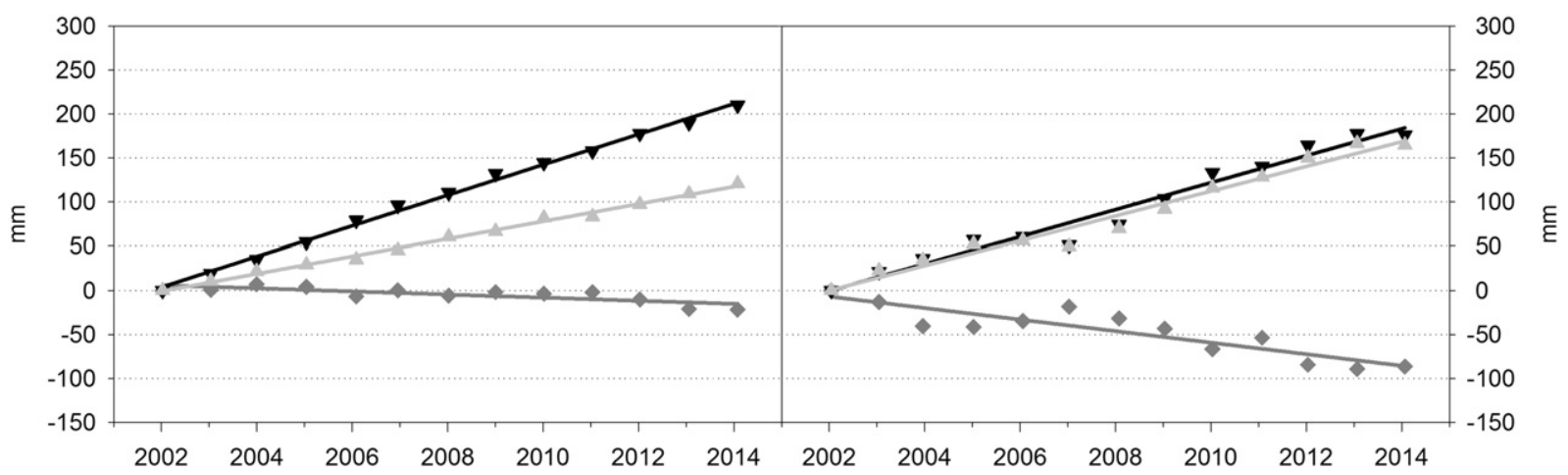

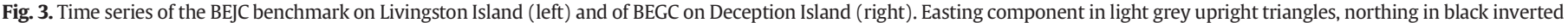
triangles and height in dark grey diamonds.

Snow, Livingston and Deception are in the transition zone between the northeastern and the southwestern regions. Subsidence is observed at the Snow, Deception and Livingston Islands' benchmarks (Fig. 5), potentially associated to a roll-back mechanism at the South Shetland Trench, like in case of the northeastern region. However, an abrupt shift in horizontal movement changing from the $\mathrm{N}$ direction observed at the SNOW benchmark on Snow Island to the NW direction at the BYER benchmark on Livingston Island clearly marks the separation of these two geodynamic regions of the South Shetland archipelago (Fig. 6). Therefore, an active fault zone separating Snow and Livingston Islands, perhaps parallel but not aligned with the Hero Fracture zone, might also contribute to separate the Byers Peninsula stress regime from the rest of the island (Alfaro et al., 2010; Kraus et al., 2008). Also, in this transition zone counter-clock block rotation was suggested by palaeostrain analysis (Alfaro et al., 2010; Maestro et al., 2007).

In fact, the Byers Peninsula seems to represent a key area for understanding the block rotational movements in the region. It has been interpreted to be an exotic terrane with a comparatively short history as part of southwestern Livingston Island, based on facies, stratigraphic and geochronological considerations (Kraus et al., 2008). It is now evident that the "intra-arc" Byers Group on Byers Peninsula (Hathway and Lomas, 1998) and the turbiditic Miers Bluff Formation on Hurd Peninsula (southeastern Livingston Island), originally believed to represent the basement to the Byers Group, are actually of the same age. Because the turbiditic depositional environment of Hurd Peninsula's Miers Bluff Formation suggests a deposition to the west of the main volcanic arc (and therefore also to the west of the contemporaneous "intra-arc" Byers Formation), it must be concluded that the present relative position of the Hurd and Byers Peninsulas are the result of a large-scale post-depositional movement, possibly along deep-cutting fault systems (Kraus et al., 2008). While it is unknown at present where exactly Byers Peninsula originally came from, it seems reasonable to think of the deep-cutting fault systems along which it possibly moved into its present location as zones of crustal instability today accommodating the block rotational movements indicated here. In fact, the new data seem to suggest that in terms of crustal stability, the region between Deception Island and Byers Peninsula (Fig. 6) is the most active area within the South Shetland Islands Microplate.

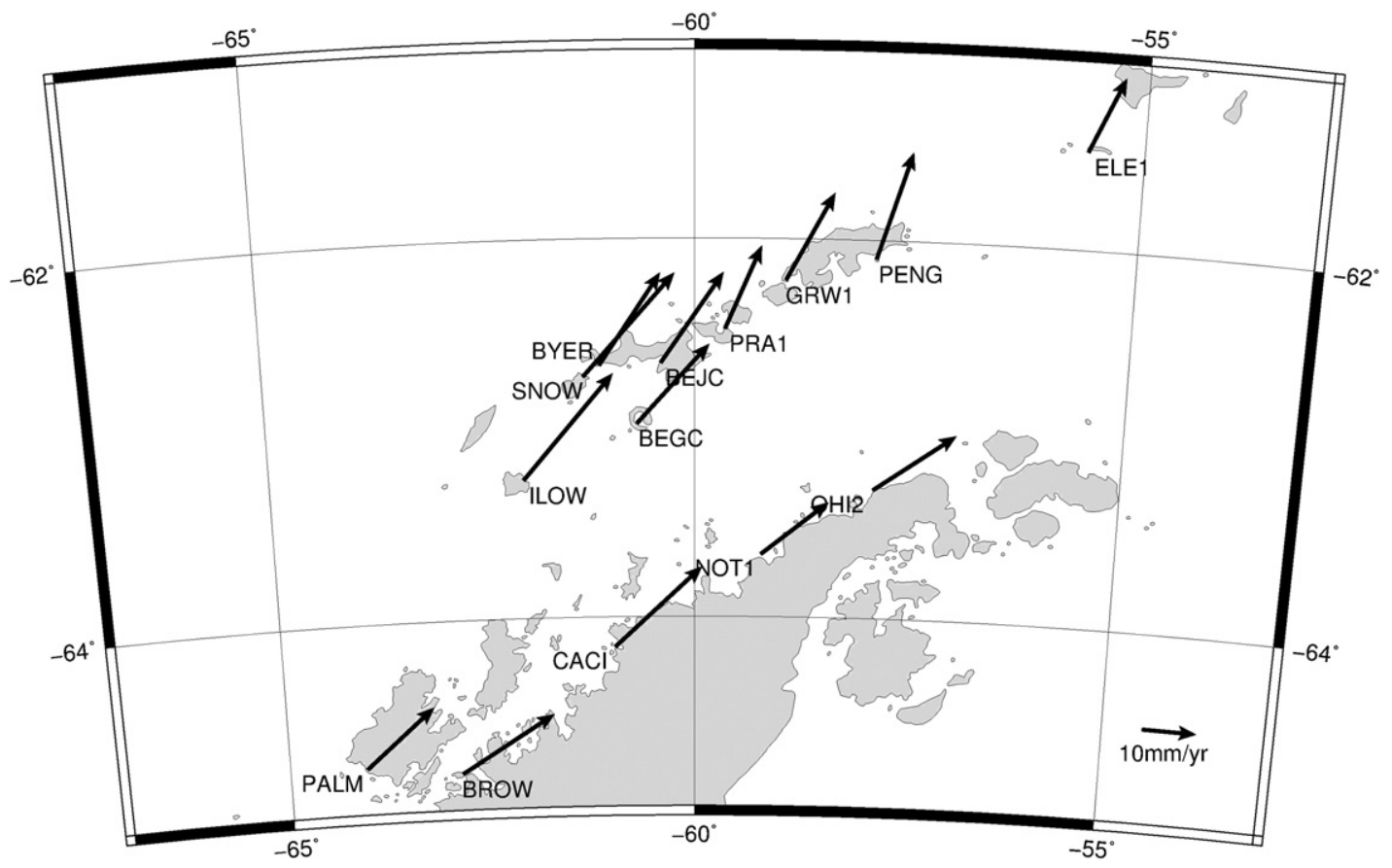

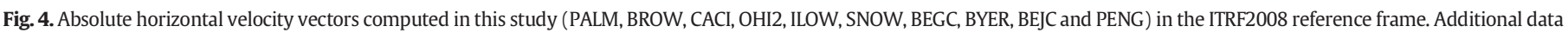
from Dietrich et al. (2004) (NOT1, PRA1 and ELE1) and Jiang et al. (2009) (GRW1) in the ITRF2000. 


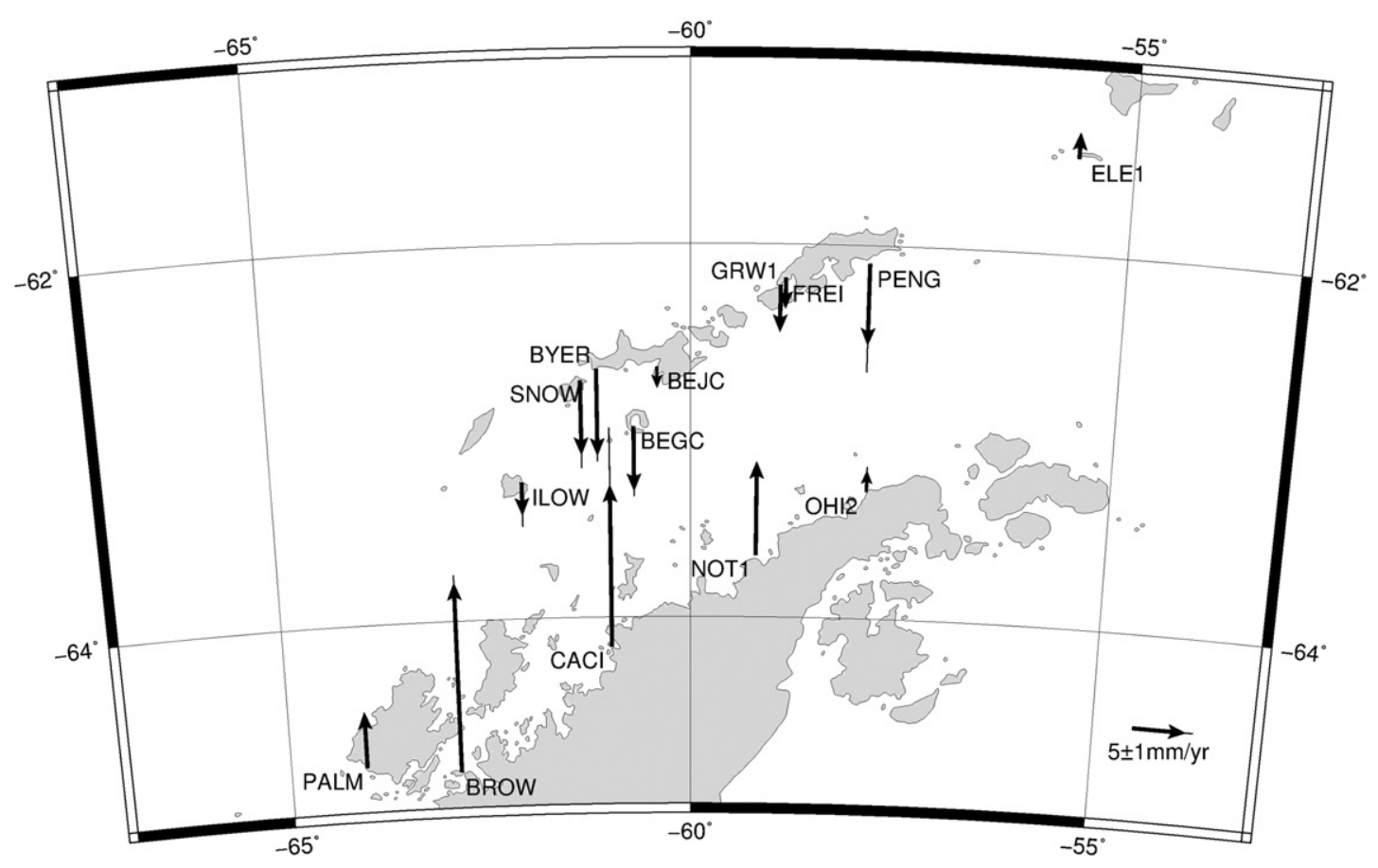

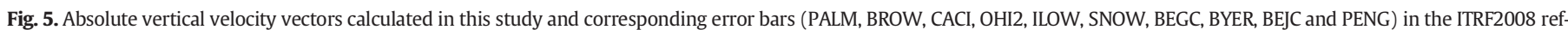
erence frame. Additional data from Dietrich et al. (2004) (NOT1 and ELE1) and Jiang et al. (2009) (GRW1) in the ITRF2000, and Bevis et al. (2009) (FREI) in the ITRF2005.

\section{Conclusions}

The RGAE network geodetic benchmarks' position time series were assessed from a geodynamic point of view. These time series show broadly linear patterns for those benchmarks at locations with exclusively tectonic regimes and less linear patterns for those located in active volcanic areas, like on Deception Island (Fig. 3). The benchmarks' velocities were computed from these time series. This study inferred benchmarks' absolute horizontal velocity vectors present similar magnitudes and directions as those presented by Dietrich et al. (2004) and Jiang et al. (2009). However, this study inferred absolute vertical velocity vectors indicate subsidence in the northeastern part of the South Shetland Islands archipelago in contrast to the uplift movement observed by Dietrich et al. (2004), but in agreement with the data published by Jiang et al. (2009) and Bevis et al. (2009). In the Antarctic Peninsula, the inferred uplift are in agreement with post-glacial

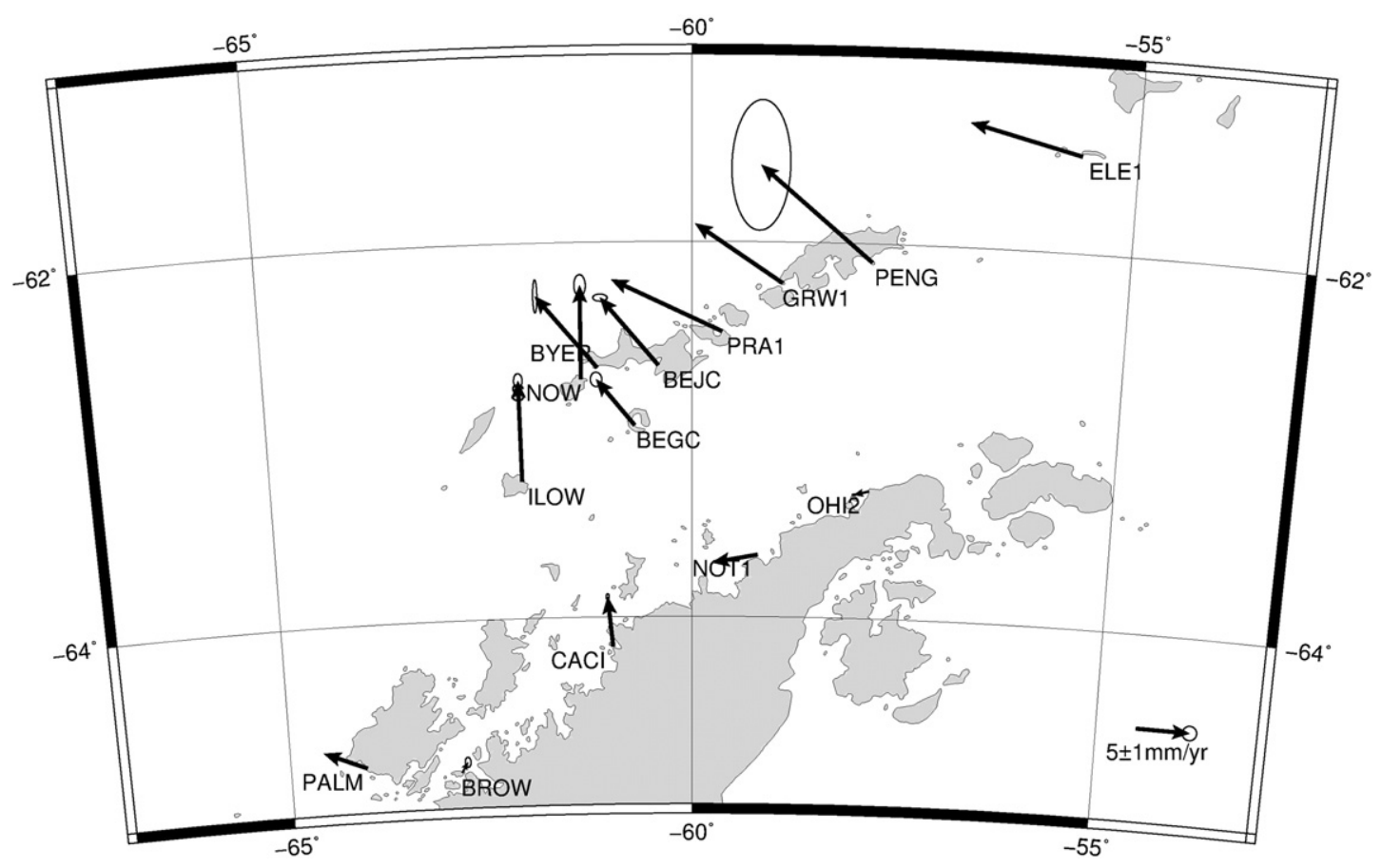

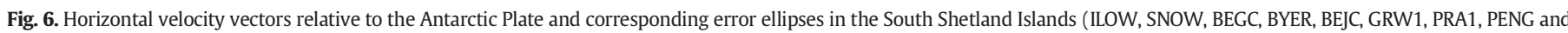
ELE1) and the Antarctic Peninsula region (PALM, BROW, CACI, NOT1 and OHI2). 


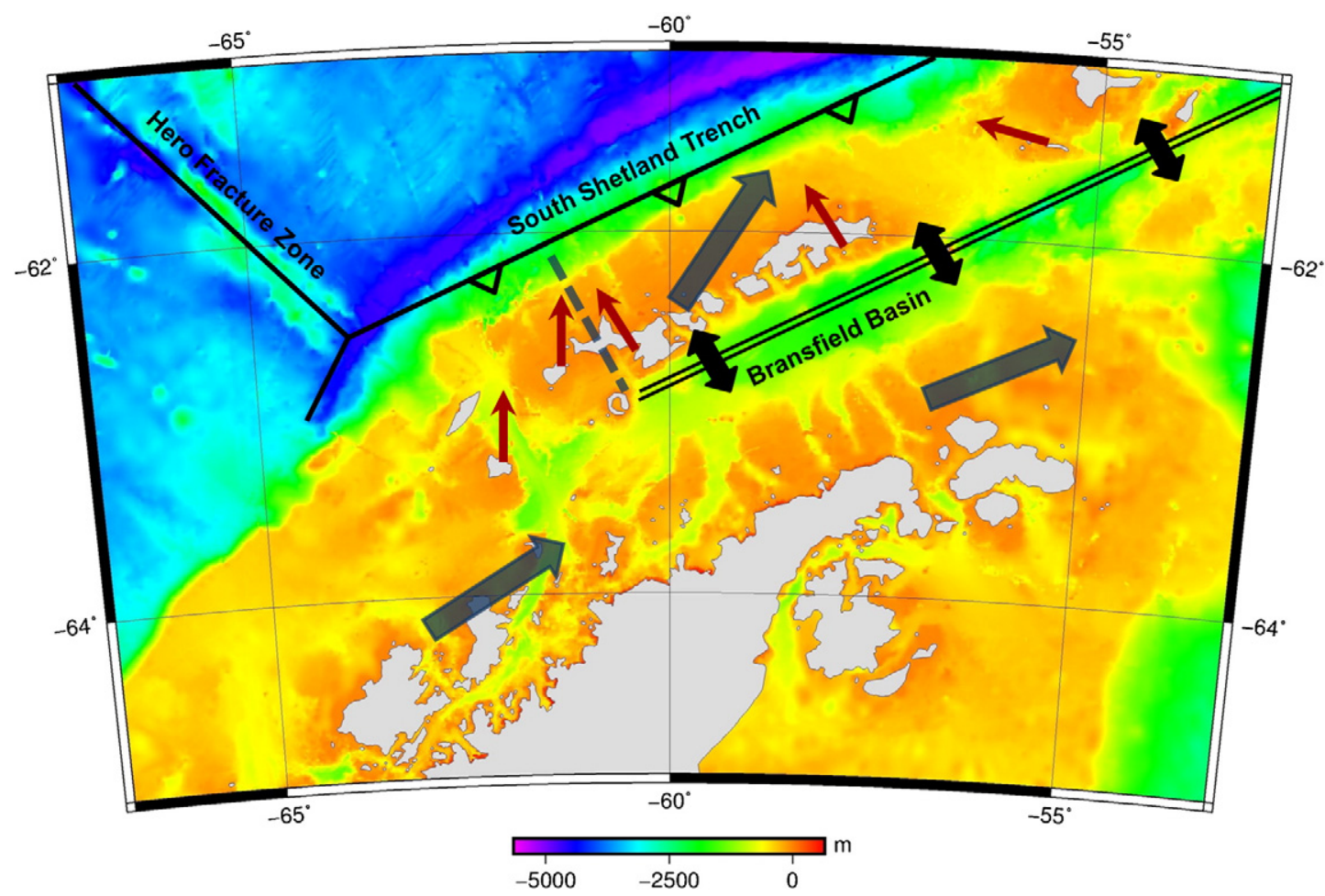

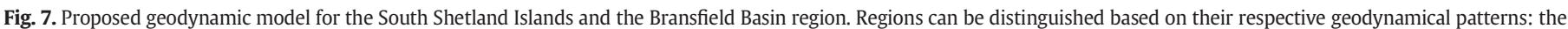

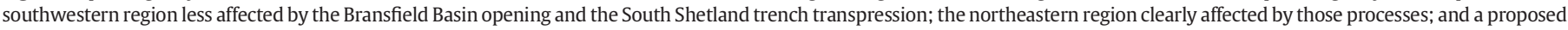

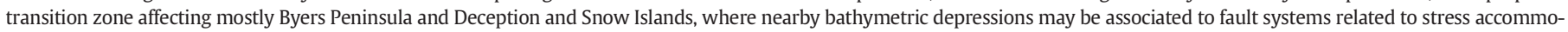

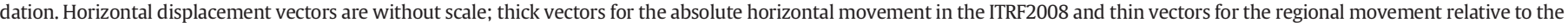
Antarctic Plate. Bathymetry from Smith and Sandwell (1999).

rebound due to glacial isostatic adjustment to the Larson B ice-shelf breakup (Argus et al., 2011b; Bevis et al., 2009; Ivins et al., 2011; Nield et al., 2014).

The horizontal velocities relative to the Antarctic Plate suggest two different regions in the South Shetland Islands archipelago characterized by distinct geodynamic patterns (Fig. 6), leading to the proposal of a new geodynamic model for the region (Fig. 7). The northwestern region, comprising the area between Livingston and Elephant Islands, is horizontally affected by the Bransfield Basin extensional regime, while subsidence observed in the same area may be related to the Phoenix Microplate roll-back underneath the South Shetland Microplate (Fretzdorff et al., 2004; González-Casado et al., 2000; González-Ferrán, 1991; Maestro et al., 2007; Prieto et al., 1998). Both the Bransfield Basin extension and the South Shetland Trench slab roll-back are at least partially a consequence of the movement of the Antarctic Plate, in this region towards the NNE against the wedge formed by the Shackleton Fracture Zone meeting the South Scotia Ridge. NNE-directed velocities diminish progressively from the Antarctic Peninsula and South Scotia Ridge side towards the former Phoenix Microplate and Shackleton Fracture Zone side. This results in extension and opening of the Bransfield Basin (because of lower northeastwards directed velocities as compared to the Antarctic Peninsula side), and possibly in slab roll-back at the South Shetland Trench (because of even lower northeastwards directed velocities than in the Bransfield Basin and South Shetland Islands region) (Fig. 7). This stress field is favorable to block faulting, breakup, and counterclockwise rotation within the Bransfield Basin and South Shetland Islands archipelago (Maestro et al., 2007). However, the southwest region comprising Smith, Low and Snow Islands is less affected by the Bransfield Basin extension and the slab roll-back at the South Shetland Trench.

A transition zone between the identified southwest and northeast regions, comprising Snow, Deception, and Livingston Islands is proposed. The subsidence vectors inferred for these islands have similar magnitude to those of the northeastern region, hence it is concluded that they are affected by the same tectonic regime related to processes along the South Shetland Trench (Fig. 5). However, SNOW on Snow Island and BYER on Livingston Island geodetic benchmarks give evidence for compression NE-SW, also inferred in the last years on Deception Island (Prates, 2012), based on their convergent horizontal movement, with the SNOW velocity direction $\mathrm{N}$ being similar to that of the southwestern region while the BYER velocity direction NW is similar to that of the northeastern region (Fig. 6). In Deception Island, the NW-SE Bransfield Basin extension, the NE-SW compressional regime inferred on Byers Peninsula, and the subsidence caused by the South Shetland Trench tectonic regime are all present.

Deception Island and Byers Peninsula may well be closely affected by active faults related to the local compressive state. This, in combination with previous evidence for Byers Peninsula being an exotic terrane that thus moved into its present position at some point during the Cenozoic, confirms its state as a key area for understanding present day crustal movements in the South Shetland Island archipelago, as well as in identifying Deception Island and Byers Peninsula region as an area of crustal instability.

\section{Acknowledgments}

This geodetic research has been carried out with the support of the Spanish Ministry of Education and Science as part of the National Antarctic Program. The following research projects contributed directly to this work: "Recognition and fast evaluation of volcanic activity on Deception Island (GEODESY) (ANT1999-1430-E/HESP)"; "Geodetic Studies on Deception Island: deformation models, geoid determination and Scientific Information System (REN2000-0551-C03-01/ANT)"; "Acquisition of scientific software for GPS data processing (REN2000-2690E)"; "Geodetic Control of the volcanic activity of Deception Island (CGL2004-21547-E/ANT)"; "Update of the Spanish Cartography for 
Deception Island (CGL2004-20408-E/ANT)”; “Volcano-tectonic activity on Deception Island: geodetic, geophysical investigations and Remote Sensing on Deception Island and its surroundings (CGL12005-07589c03-01/ANT)"; and "Geodetic and Geothermal Researches, Time Serial Analysis and Volcanic Innovation in Antarctica (South Shetland Islands and Antarctic Peninsula (GEOTINANT) (CTM2009-07251/ANT))". Both the contributions of the Editors and of two anonymous reviewers are very much appreciated, which greatly helped to improve the manuscript.

\section{References}

Alfaro, P., López-Martínez, J., Maestro, A., Galindo-Zaldívar, J., Durán-Valsero, J.J., Cuchí, J.A., 2010. Recent tectonic and morphostructural evolution of Byers Peninsula (Antarctica): insight into the development of the South Shetland Islands and Bransfield Basin. J. Iber. Geol. 36 (1), 21-38.

Altamimi, Z., Collilieux, X., Métivier, L., 2011. ITRF2008: an improved solution of the International Terrestrial Reference Frame. J. Geod. 85 (8), 457-473. http://dx.doi.org/10. 1007/s00190-011-0444-4.

Argus, D.F., Gordon, R.G., DeMets, C., 2011a. Geologically current motion of 56 plates relative to the no-net-rotation reference frame. Geochem. Geophys. Geosyst. 12, Q11001. http://dx.doi.org/10.1029/2011GC003751.

Argus, D.F., Blewitt, G., Peltier, W.R., Kreemer, C., 2011b. Rise of the Ellsworth mountains and parts of the East Antarctic coast observed with GPS. Geophys. Res. Lett. 38, L16303. http://dx.doi.org/10.1029/2011GL048025.

Barker, P.F., 1976. The tectonic framework of Cenozoic volcanism in the Scotia Sea region - a review. In: González-Ferrán, O. (Ed.), Proceedings of the Symposium on Andean and Antarctic Volcanology Problems. International Association of Volcanology and Chemistry of the Earth's Interior, Rome, pp. 330-346.

Barker, P.F., 1982. The Cenozoic subduction history of the Pacific margin of the Antarctic Peninsula: ridge-crest trench interactions. J. Geol. Soc. Lond. 139, 787-801.

Barker, P.F., Dalziel, I.W.D., Storey, B.C., 1991. Tectonic development of the Scotia arc region. In: Tingey, R.J. (Ed.), The geology of AntarcticaMonogr. on Geol. and Geophys 17. Oxford Science Publ, pp. 215-248.

Barker, D.H.N., Christeson, G.L., Austin Jr., J.A., Dalziel, W.D., 2003. Backarc basin evolution and cordilleran orogenesis: insights from new ocean-bottom seismograph refraction profiling in Bransfield Strait, Antarctica. Geology 31, 107-110.

Berrocoso, M., Ramírez, M.E., Fernández-Ros, A., 2006. Horizontal deformation models for the Deception Island. In: Sansó, F. Gil, AJ. (Eds.), Geodetic Deformation Monitoring: From Geophysical to Engineering Roles 131. International Association of Geodesy Symposia (IAG), pp. 217-221.

Berrocoso, M., Fernández-Ros, A., Ramírez, M.E., Salamanca, J.M., Torrecillas, C., PérezPeña, A., Páez, R., García-García, A., Jiménez-Teja, Y., García-García, F., Soto, R. Gárate, J., Martín-Davila, J., Sánchez-Alzola, A., de Gil, A., Fernández-Prada, J.A., Jigena, B., 2008. Geodetic research on Deception Island and its environment (South Shetland Islands, Bransfield Sea and Antarctic Peninsula) during Spanish Antarctic campaigns (1987-2007). In: Capra, A., Dietrich, R. (Eds.), Geodetic and Geophysical Observations in Antarctica, pp. 97-124.

Berrocoso, M., Prates, G., Fernández-Ros, A., García, A., 2012. Normal vector analysis from GNSS-GPS data applied to Deception volcano surface deformation. Geophys. J. Int 190, 1562-1570.

Bevis, M., Kendrick, E., Smalley Jr., R., Dalziel, I., Caccamise, D., Sasgen, I., Helsen, M., Taylor, F.W., Zhou, H., Brown, A., Raleigh, D., Willis, M., Wilson, T., Konfal, S., 2009. Geodetic measurements of vertical velocity in West Antarctica and the implications for ice mass balance. Geochem. Geophys. Geosyst. 10 (10), Q10005. http://dx.doi.org/10. 1029/2009GC002642.

Canals, M., Gracia, E., Grupo, G.E.B.R.A., 1997. Evidence of initial seafloor spreading in the Central Bransfield Basin, Western Antarctica. Bol. R. Soc. Esp. Hist. Nat. 93 (1-4), 53-61 (Sección Geología).

Carmona, E., Almendros, J., Serrano, I., Stich, D., Ibáñez, J.M., 2012. Results of seismic monitoring surveys of Deception Island volcano, Antarctica, from 1999-2011. Antarct. Sci. $24,485-499$.

Bernese GPS Software Ver. 5.0 User manual. In: Dach, R., Hugentobler, U., Fridez, P., Meindl, M. (Eds.), Astronomical Institute, University of Bern.

Dietrich, R., Dach, R., Engelhardt, G., Ihde, J., Korth, W., Kutterer, H., Lindner, K., Mayer, M., Menge, F., Miller, H., Müller, C., Niemeier, W., Perlt, J., Pohl, M., Salbach, H., Schenke, H.W., Schöne, T., Seeber, G., Veit, A., Völksen, C., 2000. Ergebnisse der SCAR GPS Kampagnen - ITRF-Koordinaten und Geschwindigkeiten. In: Dietrich, R. (Ed.), Deutsche Beiträge zu GPS-Kampagnen des Scientific Committee on Antarctic Research (SCAR), 1995-1998. Reihe B, Angewandte Geodäsie 310, pp. 11-20.

Dietrich, R., Dach, R., Engelhardt, G., Ihde, J., Korth, W., Kutterer, H.J., Lindner, K., Mayer, M., Menge, F., Miller, H., Müller, C., Niemeier, W., Perlt, J., Pohl, M., Salbach, H. Schenke, H.W., Schöne, T., Seeber, G., Veit, A., Völksen, C., 2001. ITRF coordinates and plate velocities from repeated GPS campaigns in Antarctica - an analysis based on different individual solutions. J. Geod. 74, 756-766.

Dietrich, R., Rülke, A., Ihde, J., Lindner, K., Miller, H., Niemeier, W., Schenke, H.W., Seeber, G., 2004. Plate kinematics and deformation status of the Antarctic Peninsula based on GPS. Global Planet. Change 42 (1-4), 313-321.

Fretzdorff, S., Worthington, T.J., Haase, K.M., Hékinian, R., Franz, L., Keller, R.A., Stoffers, P., 2004. Magmatism in the Bransfield Basin: rifting of the South Shetland Arc? J. Geophys. Res. 109, B12208.
Galindo-Zaldívar, J., Gamboa, L., Maldonado, A., Nakao, S., Bochu, Y., 2004. Tectonic development of the Bransfield Basin and its prolongation to the South Scotia Ridge, northern Antarctic Peninsula. Mar. Geol. 206 (1-4), 267-282.

Galindo-Zaldívar, J., Maestro, A., López-Martínez, J., Sanz-Galdeano, C., 2006. Elephant Island recent tectonics in the framework of the Scotia-Antarctic-South Shetland Block triple junction (NE Antarctic Peninsula). In: Fütterer, D.K., Damaske, D. Kleinschmidt, G., Miller, H., Tessensohn, F. (Eds.), Antarctic Contributions to Global Earth Science, pp. 271-276.

García, A., DECVOL Working Group, 2002. A crossdisciplinary study at Deception Island (South Shetland Islands, Antarctica). Evaluation of the Recent Volcanological Status, Consejo Superior de Investigaciones Científicas, Museo Nacional de Ciencias Naturales.

González-Casado, J.M., Giner-Roles, J.L., López-Martinez, J., 2000. Bransfield Basin, Antarctic Peninsula: not a normal backarc basin. Geology 28, 1043-1046.

González-Ferrán, O., 1983. The Larsen Rift: an active extension fracture in West Antarctica. In: Oliver, R., James, P., Jago, J. (Eds.), Antarctic Earth Science, pp. 344-346.

González-Ferrán, O., 1991. The Bransfield rift and its active volcanism. In: Thomson, R.A. Crame, J.A., Thomson, J.W. (Eds.), Geological Evolution of Antarctica, pp. 505-509.

González-Ferrán, O., 1995. Volcanes de Chile. Instituto Geográfico Militar, Santiago, Chile.

Hathway, B., Lomas, S.A., 1998. The Upper Jurassic-Lower Cretaceous Byers Group, South Shetland Islands, Antarctica: revised stratigraphy and regional correlations. Cretac. Res. 19, 43-67.

Henriet, J.P., Meissner, R., Miller, H., Team, G.R.A.P.E., 1992. Active margin processes along the Antarctic Peninsula. Tectonophysics 201, 229-253.

Ibáñez, J.M., del Pezzo, E., Almendros, J., la Rocca, M., Alguacil, G., Ortiz, R., García, A., 2000. Seismovolcanic signals at Deception Island Volcano, Antarctica: wavefield analysis and source modeling. J. Geophys. Res. 105, 13905-13931.

Ibáñez, J.M., Carmona, E., Almendros, J., Saccorotti, G., del Pezzo, E., Abril, M., Ortiz, R., 2003. The 1998-1999 seismic series at Deception Island volcano, Antarctica J. Volcanol. Geotherm. Res. 128 (1-3), 65-88.

Ivins, E.R., Watkins, M.M., Yuan, D.-N., Dietrich, R., Casassa, G., Rülke, A., 2011. On-land ice loss and glacial isostatic adjustment at the Drake Passage: 2003-2009. J. Geophys. Res. 116 (B2), B02403. http://dx.doi.org/10.1029/2010JB007607.

Jiang, W.P., E, D.C., Zhan, B.W., Liu, Y.W., 2009. New model of antarctic plate motion and its analysis. Chin. J. Geophys. 52, 23-32. http://dx.doi.org/10.1002/cjg2.1323.

Jin, Y.K., Lee, J., Hong, J.K., Nam, S.H., 2009. Is subduction ongoing in the South Shetland Trench, Antarctic Peninsula?: new constraints from crustal structures of outer trench wall. Geosci. J. 13 (1), 59-67.

Kraus, S., Miller, H., Dimov, D., Hegner, E., McWilliams, M., Pecscay, Z., 2008. Structural geology of the Miers Bluff Formation (Upper Jurassic-Upper Cretaceous) and crosscutting Paleogene dikes (Livingston Island, South Shetland Islands, Antarctica) insights into the geodynamic history of the northern Antarctic Peninsula. J. S. Am. Earth Sci. 26 (4), 498-512.

Kraus, S., Poblete, F., Arriagada, C., 2010. Dike systems and their volcanic host rocks on King George Island, Antarctica: Implications on the geodynamic history based on a multidisciplinary approach. Tectonophysics 495 (3-4), 269-297.

Kraus, S., Kurbatov, A., Yates, M., 2013. Geochemical signatures of tephras from Quaternary Antarctic Peninsula volcanoes. Andean Geol. 40 (1), 1-40.

Larter, R.D., Barker, P.F., 1991. Effects of ridge-crest trench interaction on Antarctic-Phoenix Spreading: forces on a young subducting plate. J. Geophys. Res. 96, 19583-19607.

Livermore, R., Balanyá, J.C., Maldonado, A., Martínez, J.M., Rodríguez-Fernández, J., SanzGaldeano, C., Galindo-Zaldívar, J., Jabaloy, A., Barnolas, A., Somoza, L., HernándezMolina, J., Suriñach, E., Viseras, C., 2000. Autopsy on a dead spreading center: the Phoenix Ridge, Drake Passage, Antarctica. Geology 28, 607-610.

López-Martínez, J., Trouw, R.A.J., Galindo-Zaldívar, J., Maestro, A., Simões, L.S.A., Medeiros, F.F., Trouw, C.C., 2006. Tectonics and geomorphology of Elephant Island, South Shetland Islands. In: Fütterer, D.K., Damaske, D., Kleinschmidt, G., Miller, H., Tessensohn, F. (Eds.), Antarctic Contributions to Global Earth Science, pp. 277-281.

Maestro, A., Somoza, L., Rey, J., Martinez-Frias, J., Lopez-Martinez, J., 2007. Active tectonics, fault patterns, and stress field of Deception Island: a response to oblique convergence between the Pacific and Antarctic plates. J. S. Am. Earth Sci. 23, 256-268.

Mervart, L., 1995. Ambiguity Resolution Techniques in Geodetic and Geodynamic Applications of the Global Positioning System. University of Bern (PhD thesis).

Muñoz-Martín, A., Catalán, M., Martín-Dávila, J., Carbo, A., 2005. Upper crustal structure of Deception Island area (Bransfield Strait, Antarctica) from gravity and magnetic modeling. Antarct. Sci. 17 (2), 213-224.

Nield, G.A., Barletta, V.R., Bordoni, A., King, M.A., Whitehouse, P.L., Clark, P.J., Domack, E., Scambos, T.A., Berthier, E., 2014. Rapid bedrock uplift in the Antarctic Peninsula explained by viscoelastic response to recent ice unloading. Earth Planet. Sci. Lett. 397, 32-41.

Niell, A.E., 1996. Global mapping functions for the atmosphere delay at radio wavelengths. J. Geophys. Res. 101 (B2), 3227-3246.

Pérez-López, R., Giner-Robles, J.L., Martínez-Díaz, J.J., Rodríguez-Pascua, M.A., Bejar, M. Paredes, C., Gonzá-lez-Casado, J.M., 2007. Active tectonics on Deception Island (West-Antarctica): a new approach by using the fractal anisotropy of lineaments, fault slip measurements and the caldera collapse shape. In: Cooper, A.K., Raymond, C.R., et al. (Eds.), Antarctica: A Keystone in a Changing World, Proceedings of the 10th ISAES http://dx.doi.org/10.3133/of2007-1047.srp086.

Prates, G., 2012. GNSS-GPS geodetic time series treatment for volcanic activity monitoring and surveillance: spatial dilatometer and inclinometer. Applied to Deception (Antarctica) and El Hierro (Canaries) Islands. Universidad de Cádiz (PhD Thesis).

Prates, G., Berrocoso, M., Fernández-Ros, A., García, A., 2013. Enhancement of sub-daily positioning solutions for surface deformation monitoring at Deception volcano (South Shetland Islands, Antarctica). Bull. Volcanol. 75, 1-10.

Prieto, M.J., Canals, M., Ercilla, G., de Batist, M., 1998. Structure and geodynamic evolution of the Central Bransfield Basin (NW Antarctica) from seismic reflection data. Mar. Geol. 149 (1-4), 17-38. 
Robertson, S.D., Wiens, D.A., Shore, P.J., Smith, G.P., Vera, E., 2002. Seismicity and tectonics of the South Shetland Islands and Bransfield Strait from the SEPA broadband seismograph deployment. Roy. Soc. N. Z. Bull. 35, 549-554.

Robertson-Maurice, S.D., Wiens, D.A., Shore, P.J., Vera, E., Dorman, L.M.M., 2003. Seismicity and tectonics of the South Shetland Islands and Bransfield Strait from a regional broadband seismograph deployment. J. Geophys. Res. 108 (B10), 2461-2472.

Saastamoinen, I., 1973. Contribution of the theory of atmospheric refraction In three parts Bull. Géodésique 105, 279-298 (106, 383-397, 107, 13-34.).

Smalley Jr., R., Dalziel, I.W.D., Bevis, M.G., Kendrick, E., Stamps, D.S., King, E.C., Taylor, F.W. Lauría, E., Zakrajsek, A., Parra, H., 2007. Scotia arc kinematics from GPS geodesy. Geophys. Res. Lett. 34, L21308. http://dx.doi.org/10.1029/2007GL031699.

Smellie, J.L., Pankhurst, R.J., Thomson, M.R.A., Davies, R.E.S., 1984. The geology of the South Shetland Islands: VI, Stratigraphy. Geochemistry and Evolution, British Antarctic Survey Scientific Reports. 87.

Smith, W.H.F., Sandwell, D.T., 1999. Global seafloor topography from satellite altimetry and ship depth soundings. Science 277, 1957-1962.
Solari, M.A., Hervé, F., Martinod, J., le Roux, J.P., Ramirez, L.E., Palacios, C., 2008. Geotectonic evolution of the Bransfield basin, Antarctic Peninsula: insights from analogue models. Antarct. Sci. 20, 185-196.

Taylor, F.W., Bevis, M.G., Dalziel, IW.D., Smalley Jr., R., Frohlich, C. Kendrick, E., Foster, J., Phillips, D., Gudipati, K., 2008. Kinematics and segmentation of the South Shetland Islands-Bransfield basin system, northern Antarctic Peninsula. Geochem. Geophys. Geosyst. 9, Q04035.

Thomas, C., Livermore, R., Pollitz, F., 2003. Motion of the Scotia Sea plates. Geophys. J. Int. 155, 789-804.

Tokarski, A.K., 1991. The Late Cretaceous-Cenozoic structural history of King George Island, South Shetland Islands, and its plate-tectonic setting. In: Thomson, M.R.A., Crame, J.A., Thomson, J.W. (Eds.), Geological Evolution of Antarctica, pp. 417-422.

Uhlein, A., Trompette, R.R., Rocha-Campos, A.C., dos Santos, P.R., Gipp, M., Simões, J.C., 1993. Regime compresivo atrás de una zona de subducçao: juntas subhorizontais no arco magmático cenozoico da Ilha Rei George. Soc. Bras. Geol. 12, 330-339 (IV Simp. Bras. Geol) 